\title{
Influence of ocean currents on long-distance movement of leatherback sea turtles in the Southwest Indian Ocean
}

\author{
Paolo Lambardi ${ }^{1}$, Johann R. E. Lutjeharms ${ }^{2}$, Resi Mencacci ${ }^{1}$, Graeme C. Hays ${ }^{3}$, \\ Paolo Luschi ${ }^{1, *}$ \\ ${ }^{1}$ Dipartimento di Biologia, Università di Pisa, Via A. Volta 6, 56126 Pisa, Italy \\ ${ }^{2}$ Department of Oceanography, University of Cape Town, Rondebosch 7700, South Africa \\ ${ }^{3}$ Department of Biological Sciences, Institute of Environmental Sustainability, University of Wales Swansea, Singleton Park, \\ Swansea SA2 8PP, UK
}

\begin{abstract}
Leatherback turtles Dermochelys coriacea spend most of their life in oceanic environments, whose physical and biological characteristics are primarily forged by sea current circulation. Water mass movements can mechanically act on swimming turtles, thus determining their routes, and can differentially distribute their planktonic prey. By integrating satellite tracking data with contemporaneous remote-sensing information, we analysed the post-nesting journeys of 9 leatherbacks with respect to oceanographic surface conditions. Tracked turtles showed large variations in migration routes and in final destinations, apparently without heading for specific foraging areas. Their complex tracks spread over wide regions around South Africa. Leatherbacks were greatly influenced by the currents encountered during their movements, with their trajectories displaying curves or revolutions in the presence of (and in accordance with) rotating water masses. An impressive similarity was observed between large parts of the turtle routes and those of surface drifters tracked in the same regions. Finally, leatherbacks remained associated for long periods with specific oceanographic features, which most probably offered them profitable foraging opportunities. These results agree with previous findings in showing a strong influence of oceanic currents and mesoscale features on the movements of South African leatherbacks, and additionally identify the role of current-related features in causing the observed route variability and in determining high-quality foraging hotspots for leatherbacks moving in the ocean.
\end{abstract}

KEY WORDS: Satellite telemetry $\cdot$ Dermochelys $\cdot$ Remote sensing $\cdot$ Oceanography $\cdot$ Current drift

\section{INTRODUCTION}

For animals travelling in a moving medium, the movement of the medium may have profound impacts on the animal's trajectory. Classic examples concern the impact of wind on the journeys of birds and of ocean currents on the movement of marine animals, especially as regards larval dispersion (Dingle 1996, Alerstam et al. 2003). However, currents may also affect nektonic animals capable of strong active swimming, like sea turtles (Luschi et al. 2003a). Turtle hatchlings are advected around entire ocean basins by currents (Musick \& Limpus 1997), but adult turtles could also be affected by current circulation in their movements (e.g. Girard et al. 2006). This applies even to the largest species of turtle, the pelagic-dwelling leatherback turtle Dermochelys coriacea, whose preferences for patchily distributed pelagic prey cause it to wander over large regions while feeding on macroplankton. Indeed, satellite tracking studies have shown that leatherbacks carry out extensive oceanic movements, following complex routes showing a high degree of inter- and intra-individual variation (Morreale et al. 1996, Eckert \& Sarti 1997, Luschi et al. 
2003b, Ferraroli et al. 2004, Hays et al. 2004a,b, 2006, James et al. 2005, Eckert 2006).

The oceanic areas visited by foraging turtles are mainly characterised by sea currents and related features, which can influence leatherback feeding-related movements in 2 main ways: (1) currents exert mechanical actions on swimming animals, thus affecting the shape of the route taken; (2) oceanic circulation is responsible for differential distributions of food resources in the ocean, determining the distribution of planktonic primary producers, and thus also of animals at higher trophic levels, including top predators like leatherbacks. In particular, eddies may concentrate nutrients and organisms, and thus represent patches of high prey abundance targeted by foraging turtles. By integrating satellite tracking findings with contemporaneous oceanographic data, the influence of these processes on ocean-moving leatherbacks can be reliably investigated. For instance, analysing the relationship between the turtle movement direction and the water flow in that area can highlight the marked influence of currents on turtle movements (e.g. Gaspar et al. 2006). Similarly, if specific oceanographic elements provide important feeding opportunities for turtles, prolonged sojourns in those areas would be expected.

For the present study, we compiled tracking data from 9 leatherback turtles tracked over 8 yr during their wide-range oceanic movements in the SW Indian Ocean, and we integrated these with available oceanographic information. Three of these routes have been discussed in a previous paper (Luschi et al. 2003b), in which only sea current effects on the general route shapes were considered. Their inclusion in the present study allowed us to analyse movements performed over several years and varying in course and destinations, and thus to also investigate whether, and to which extent, intra- and inter-individual variations in migration patterns are linked to the spatio-temporal variability in oceanographic conditions of the region.

\section{MATERIALS AND METHODS}

Turtles and transmitters. Nine female leatherbacks nesting in the Maputaland Marine Reserve, on the eastern coast of South Africa, were followed through the Argos system during their post-nesting movements between 1996 and 2003. Three different models of transmitters, produced by Telonics and by the Sea Mammal Research Unit (University of St. Andrews, UK), were used. They were programmed with different duty cycles (Table 1) and placed on the carapace with harnesses (Luschi et al. 2003b). The Argos system provided location data classified into 6 accuracy levels, and the routes were reconstructed using all fixes and filtering out locations on land or producing ground speed values $>10 \mathrm{~km} \mathrm{~h}^{-1}$ (a threshold estimated from high-accuracy locations only).

Study area: physical setting. The SW Indian Ocean is an optimal region in which to investigate the behaviour of marine animals in relation to ocean currents. While the water flow of this region is dominated by the greater Agulhas Current system (Fig. 1a), a wide range of current types, water speeds, scales of motion and potential food sources are found here (Lutjeharms 2006).

The most prominent current in the SW Indian Ocean is the Agulhas Current, which flows along the east coast of South Africa following the continental shelf edge quite closely with a very stable trajectory. The current starts somewhere between the cities of Durban and Maputo, but the location of its northern-

Table 1. Summary information for the 9 turtles tracked between 1996 and 2003. NA: estimation not available since 'Elena' remained in coastal waters where no reliable sea surface height anomaly (SSHA) information was accessible

\begin{tabular}{|c|c|c|c|c|}
\hline Turtle & Tracking period & $\begin{array}{c}\text { Transmitter } \\
\text { model }\end{array}$ & Duty cycle & $\begin{array}{c}\text { Percentage of } \\
\text { route determined } \\
\text { by currents }\end{array}$ \\
\hline Lara & 16 Jan-18 May 1996 & ST-14 & Continuously on & 84 \\
\hline Nemi & 31 Jan-30 Sept 1999 & ST-6 & Continuously on & 78 \\
\hline Sandra & 31 Jan-11 Sept 1999 & $\mathrm{ST}-6$ & Continuously on & 69 \\
\hline Resi & 30 Jan-16 Jun 2000 & $\mathrm{ST}-6$ & $5 \mathrm{~d}$ off/ $1 \mathrm{~d}$ on & 84 \\
\hline Elena & $\begin{array}{l}2 \text { Feb-3 Mar } 2000 \\
4 \text { Mar-2 Apr } 2000\end{array}$ & $\mathrm{ST}-6$ & $\begin{array}{l}\text { Continuously on } \\
5 \mathrm{~d} \text { off/1 d on }\end{array}$ & NA \\
\hline Ronel & $\begin{array}{l}13 \text { Feb-15 Mar } 2001 \\
16 \text { Mar-20 May } 2001\end{array}$ & ST-6 & $\begin{array}{l}\text { Continuously on } \\
5 \mathrm{~d} \text { off/1 d on }\end{array}$ & 40 \\
\hline Alice & $\begin{array}{l}13 \text { Feb-16 Mar } 2001 \\
17 \text { Mar-8 Jun } 2001\end{array}$ & $\mathrm{ST}-6$ & $\begin{array}{l}\text { Continuously on } \\
5 \mathrm{~d} \text { off/1 d on }\end{array}$ & 72 \\
\hline Imola & 13 Jan-30 Jan 2002 & SRDL & Continuously on & 93 \\
\hline Sara & 29 Jan-16 Jul 2003 & SRDL & Continuously on & 65 \\
\hline
\end{tabular}



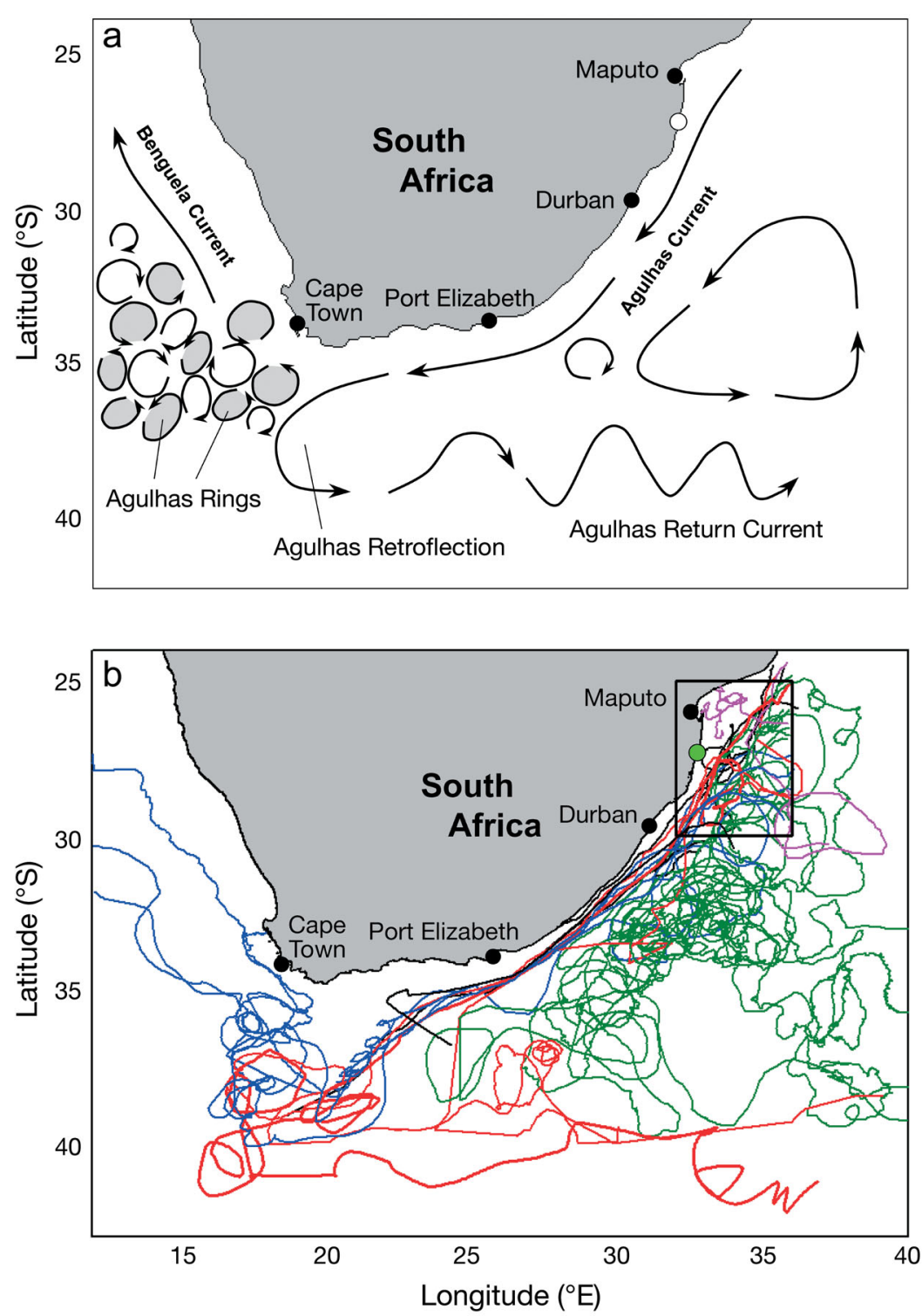

Fig. 1. (a) Schematic map of the general circulation of surface currents in the SE Atlantic and SW Indian oceans. Redrawn from Richardson et al. 2003. (b) Routes of 21 surface drifters tracked as they passed within the region delimited by the black box. Different colours highlight distinct movement patterns. Pink: drifters remaining at low latitudes; green: drifters circuiting in areas off the Agulhas mainstream; black: drifters tracked only within the Agulhas mainstream; blue: drifters entering the Atlantic Ocean; red: drifters being captured by the Agulhas Return Current (thick track: drifter shown in Fig. 4). The duration of plotted trajectories ranges from 51 to $657 \mathrm{~d}$ (mean $\pm \mathrm{SE}$, $181.9 \pm 35.1 \mathrm{~d}$ ). White and green dots: positions of turtle nesting sites

Southwest of the continent, the current retroflects with most of its water returning eastward to the Indian Ocean along the Subtropical Convergence as the Agulhas Return Current (Fig. 1a) (Lutjeharms \& Ansorge 2001). At the western termination of the Agulhas Current, huge rings of water are shed by the occlusion of the retroflection loop, subsequently drifting into the South Atlantic Ocean at 5 to $15 \mathrm{~km} \mathrm{~d}^{-1}$. The Agulhas Return Current exhibits large meanders, and its surface speed decreases with distance eastward. Events of high productivity are spasmodically found at the Subtropical Convergence (Llido et al. 2005). At 60 to $70^{\circ} \mathrm{E}$, the effect of the Agulhas Return Current is lost and the flow along the Subtropical Convergence is much weaker.

The Benguela Current (Fig. 1a) on the western side of southern Africa has entirely different characteristics. It represents the weak eastern boundary current of the SE Atlantic Ocean: estimates of the mean surface drift give average drift rates of 5 to $15 \mathrm{~km} \mathrm{~d}^{-1}$ (Wedepohl et al. 2000). Adjacent to the Benguela Current proper lies a wind-driven coastal upwelling system (Shannon \& Nelson 1996), a highly productive region extending up to the shelf edge, with occasional filaments of cold, nutrientrich water spreading far offshore (Lutjeharms et al. 1991).

Finally, the region offshore SE Africa is characterised by the passage of large eddies formed in the narrows of the Mozambique Channel and drifting poleward (de Ruijter et al. 2002). These deepsea eddies form an important component of the circulation in the area and may be joined by similarly intense eddies coming from east of Madagascar (e.g. de Ruijter et al. 2003).

This assemblage of an intense western boundary current, a weak eastern

most expression is uncertain and quite variable (Flemming \& Hay 1988). The current is 60 to $100 \mathrm{~km}$ wide at the sea surface (Beal \& Bryden 1999), and speeds in its core can exceed $7.2 \mathrm{~km} \mathrm{~h}^{-1}$, decreasing with distance offshore. Its waters are distinctly warmer and saltier than the ambient water masses, and are generally oligotrophic with strips of higher productivity at its borders (Lutjeharms 2006). boundary current adjacent to a coastal upwelling, and a host of eddies of different dimensions, intensities and senses of rotation represents nearly the full range of ocean features that marine animals could encounter anywhere in the world.

Remote sensing and oceanographic data. The reconstructed turtle routes were analysed in relation to contemporaneous satellite remote-sensing data on sea 
surface temperature (SST), sea surface height anomalies (SSHA) and chlorophyll (chl) a concentration.

SST was derived from multi-channel data sensed through the Advanced Very High Resolution Radiometer (AVHRR) on board the NOAA 14 satellite (nominally $1 \mathrm{~km}$ spatial resolution). Data were gridded by optimum interpolation by the Modular Ocean Data Assimilation System and made available by the Naval Research Laboratory (Stennis Space Center, Mississippi, USA; http://www7320.nrlssc.navy.mil/altimetry).

SSHA images, derived from measurements made by Jason, TOPEX/Poseidon, Geosat Follow-on, ERS-2 and Envisat altimetry satellites, are available from the Colorado Center for Astrodynamic Research (University of Colorado, Boulder, Colorado, USA; http://argo. colorado.edu/ realtime/gsfc_global-real-time_ssh/) in the form of $10 \mathrm{~d}$ averages ending at the given date. They reveal variations in course and speed of major currents and identify the occurrence of mesoscale oceanographic features, like eddies or filaments, while SST images give indications of the general course of the Agulhas Current. The integration of these 2 information sources is particularly valuable for portraying rapidly changing oceanographic features, such as passing eddies.

Finally, ocean colour images were obtained from the Sea-viewing Wide Field-of-view Sensor (SeaWiFS) on board the Orb-View 2 satellite (SeaWiFS Project, http://oceancolor.gsfc.nasa.gov/). They were used to get indications of the chl a concentration in the upper layers of the water column and thus, their productivity. eastern coast of South Africa were selected $(n=14)$. The possibility of placing drifters concurrently with the departure of turtles from nesting beaches would have been ideal. However, in a current as geographically stable as the Agulhas Current (Gründlingh 1983), nonsimultaneous drifters are reliable estimators for Lagrangian motion. This is not completely true outside of the current itself, where a wide range of circulation characteristics are found.

GIS software (ArcView GIS 3.2) was used to plot the routes of turtles and drifters and to superimpose the turtle routes on the remote sensing images. To calculate the percentage of each turtle route determined by ocean currents (Table 1), we summed the length of the various segments of each turtle route that were conservatively estimated to derive from the direct influence of current-related features (see next paragraph), divided by the total length of the route.

\section{RESULTS}

\section{General movement patterns}

The tracks of the 9 leatherback turtles showed a large degree of variation (Fig. 2), with a number of different movement patterns. A first distinction can be made between the 4 turtles that remained at low latitudes at least for several weeks and the 5 animals moving SW soon after leaving the nesting areas. Of these, 2 kept a course closely parallel to the South African

Additionally, we considered the existing observations of surface Lagrangian buoys tracked with Argos in the same region as turtles. Drifter data were obtained from the Atlantic Oceanographic Meteorological Laboratory (www.aoml.noaa.gov/ phod/trinanes/xbt.html). These drifters are equipped with a drogue that acts like an underwater sail, helping them to move within the current flow and minimising wind drag (Stewart 2003). In this way, they provide reliable information on the circulation of the upper layers of the water column (up to $100 \mathrm{~m}$ ), where leatherbacks spend most of their time (Sale et al. 2006). To compare these routes to those of the turtles, we chose all drifters $(n=21)$ that passed through the region from 25 to $30^{\circ} \mathrm{S}, 32$ to $36^{\circ} \mathrm{E}$ in 1996 to 2003 (see Fig. 1b). We considered the tracks of these drifters starting when they entered this region and onwards. To evaluate their speed while in the Agulhas mainstream, the track segments running along the

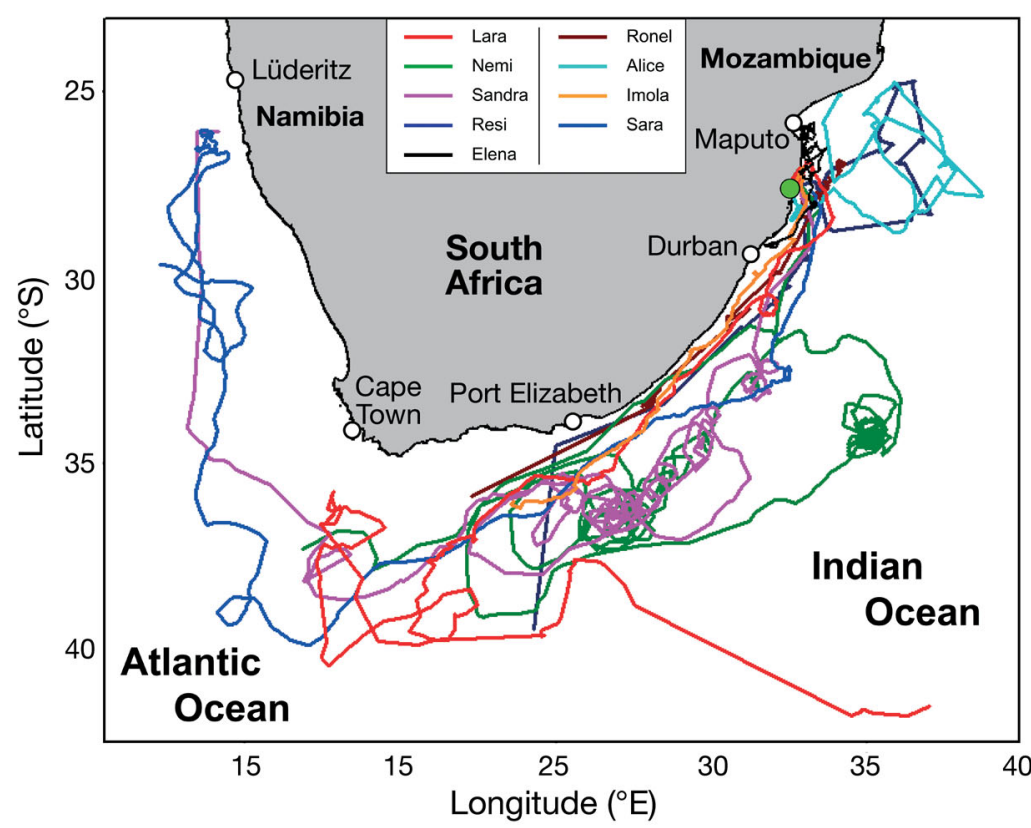

Fig. 2. Reconstructed routes of 9 leatherback turtles moving around the southernmost part of the African continent. See text and Fig. 1 for further details 
coastline, while 3 headed more offshore, in 2 cases spending long periods in seemingly restricted areas. Of the 4 former turtles, 1 ('Elena') remained in inshore waters for the whole tracking period (2 mo), while the other 3 moved offshore, where 'Resi' and 'Alice' performed large loops. Further, other patterns may also be discerned for the 2 turtles entering the SE Atlantic Ocean and for the 1 turning eastward.

Drifters passing off NE South Africa displayed movements broadly similar to those of the turtles (Fig. 1b). Three of the 21 selected buoys remained at latitudes $<30^{\circ} \mathrm{S}$ (pink routes), whereas the rest generally moved SW. Of these, 6 displayed prolonged circuitous tracks over a wide region off the Agulhas Current mainstream (green routes), with 3 of them reaching waters east of $35^{\circ} \mathrm{E}$, which were never frequented by tracked turtles. Finally, of the 12 drifters that followed the Agulhas Current mainstream, 4 entered the Atlantic basin and 3 were captured by the Agulhas Return Current (blue and red routes).

To investigate how the described general patterns of movement of leatherback turtles agree with the circulation patterns of the region, it is convenient to treat the different cases separately. 'Elena' was not considered for this analysis, as no reliable SSHA information was available for coastal regions.

\section{Movements in the Agulhas Current proper}

A rapid SW motion along the coast (Fig. 3) was the type of movement most commonly displayed by our turtles over the 8 yr period. It was usually undertaken soon after the turtles left the nesting area, although 'Resi' and 'Ronel' did so only after several weeks of residence at low latitudes. All turtles clearly moved in the same direction of the Agulhas Current main flow (Gründlingh 1983), depicted in Fig. 3 as a narrow ribbon of warm water with temperatures over $24^{\circ} \mathrm{C}$. The mean $\pm \mathrm{SE}$ speed for the 7 turtles in this leg was $79.0 \pm 13.8 \mathrm{~km} \mathrm{~d}^{-1}$, far in excess of those recorded in leatherbacks tracked in other regions to date, either during inter-nesting (28.8 to $53.6 \mathrm{~km} \mathrm{~d}^{-1}$; Keinath \& Musick 1993, Eckert 2002) or post-nesting (34.0 to $71.2 \mathrm{~km} \mathrm{~d}^{-1}$; Duron-Dufrenne 1987 , Lutcavage et al. 2002, Ferraroli et al. 2004). While the current contribution to these speeds is not known in any case, this comparison clearly indicates that South African turtles were substantially helped in their movements by the rapid flow of the Agulhas Current.

Surface drifters moved along the same route as the 7 turtles at a comparable speed $\left(76.3 \pm 7.8 \mathrm{~km} \mathrm{~d}^{-1}\right.$; $\mathrm{n}=14$ ). Inter-annual variations were recorded in the turtle speeds during this leg, which paralleled similar variations in drifters (Fig. 3 insert). Apart from the general downstream tendency, the turtle motion in the Agulhas Current also included other indicative patterns. At about the half-way point of their SW leg, 3 turtles made a seaward excursion at about $32^{\circ} \mathrm{S}$ ('Sara', 'Nemi' and 'Sandra'; Fig. 2), approximately at the location of intermittent loss of water from the Agulhas Current toward the central SW Indian Ocean (Lutjeharms \& van Ballegooyen 1988, Lutjeharms et al. 1992). Indeed, SST images (Fig. 3) clearly show that such a loss occurred in February 1999 (when 'Sandra' and 'Nemi' made the excursion), while no direct evidence is available for 'Sara' in 2003. 
The similarity between the movement of drifters and turtles may extend into the Agulhas Retroflection and Return Current region. For instance, the tracks of 'Lara' and 1 drifter shown in Fig. 4 were both recorded in 1996, but about 4 mo apart, and provide important indications of how closely turtles are tied to the water movement in the region south of the continent. A major consistency was the tendency of the turtle and the drifter to follow the water through the turbulent Agulhas Retroflection and to emerge in the Agulhas Return Current. When approaching the Retroflection region, both the turtle and the drifter underwent extensive anti-clockwise motion at about $22^{\circ} \mathrm{E}$ : 'Lara' once, and the drifter twice. This can therefore be assumed to have been the general location of the Agulhas Retroflection at the time. Both then escaped from the Retroflection carrying out gyrations in Agulhas rings to the west of the Retroflection. Subsequently, they were both carried away in the Agulhas Return Current, albeit during rather different periods (April vs. October 1996).

On the whole, when tracked turtles found themselves within the Agulhas Current mainstream, their movement fit closely with the SW current flow. On the other hand, the Agulhas mainstream possibly offered few feeding opportunities to leatherbacks, as no clear signal of enhanced productivity in this region was identifiable from ocean colour images. During their stay in this area, the turtles indeed frequented waters where the chl a density was always below $0.2 \mathrm{mg} \mathrm{m}^{-3}$.

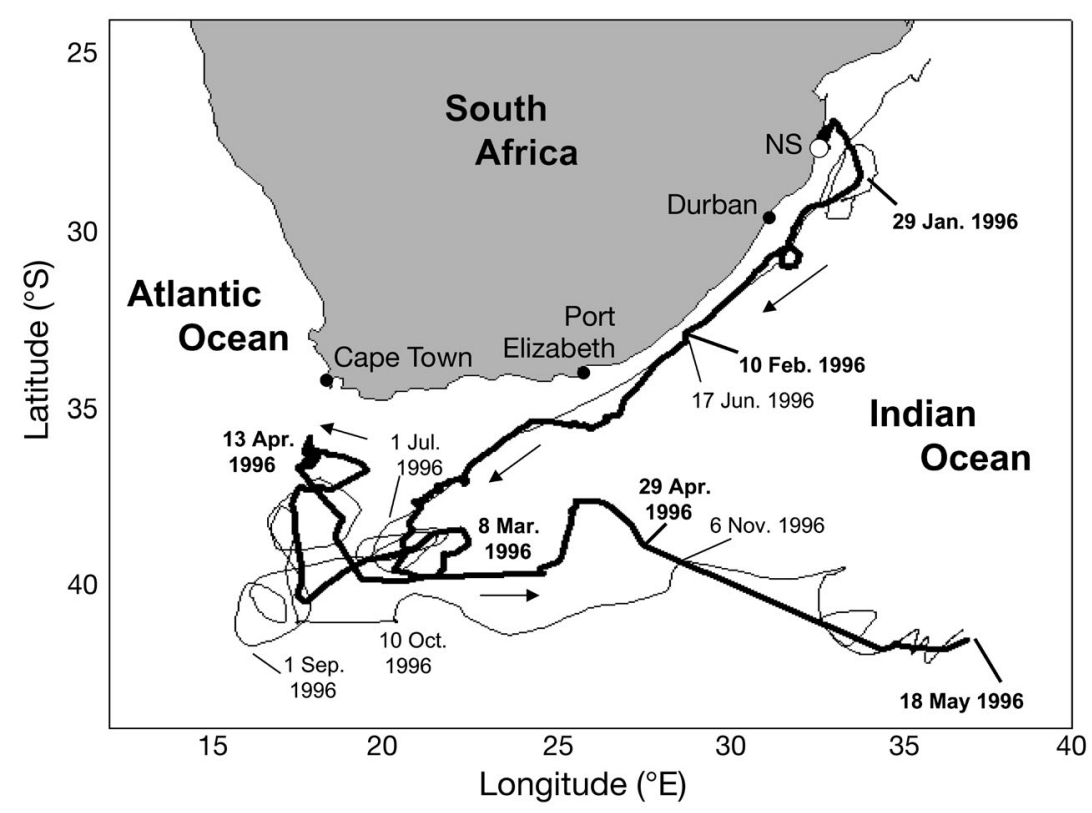

Fig. 4. Tracks of the turtle 'Lara' (thick line) and of a surface drifter (no. 9421931; thin line) moving in the Indian Ocean in 1996. NS: nesting site

\section{The inter-oceanic shift}

Two turtles ('Sandra' and 'Sara') made an inter-oceanic shift to the Atlantic Ocean (Fig. 2). In this case, surface currents also played a major role in determining this movement, highlighted as well by the frequent occurrence of such shifts in surface drifters (Fig. 1b). Both turtles, which were tracked in different years, were clearly in the core of the Agulhas Current during the last part of their journey in the Indian Ocean (see Fig. 5a for 'Sara'), moving at rates of 62.3 and $119.6 \mathrm{~km} \mathrm{~d}^{-1}$, respectively, between the longitudes of Port Elizabeth and Cape Town. As evident in the SST images, they then moved out of the main current from the western edge of the Agulhas Retroflection, without being retained in the Retroflection loop. During this shift, their movements were in accordance with the main surface circulation in the area. SSHA images show that the region directly west of the Retroflection was indeed filled with a collection of eddies (Fig. 5b for 'Sara'), which were moving NW at the time. The influence of such features on turtle movements is shown comprehensively by the track of 'Sara' (Fig. 5b), which followed the contours of SSHA fairly well. On escaping from the Agulhas Retroflection, she was caught by an anti-cyclonic eddy that made her track loop anti-clockwise (around 13 March). A second anti-cyclonic eddy subsequently led her to culminate in the farthest eastward divergence from a straight meridional track (16 March), before leading her to the westernmost excursion on 21 March.

Entering the Atlantic Ocean allowed 'Sandra' and 'Sara' to access the upwelling regions along the west coast of southern Africa, where large concentrations of gelatinous macroplankton occur (Brierley et al. 2001). They indeed moved equatorward (Fig. 2), marginally following the weak flow of the Benguela Current and keeping outside the main corridor of intense northwest-oriented Agulhas rings (Schouten et al. 2000). They stayed outside the intense part of the coastal upwelling and only at a latitude of $26^{\circ} \mathrm{S}$ did they move toward it. There is no clear indication from any environmental data that this coastal approach was induced by any ocean currents.

\section{Mesoscale eddies}

Eddies represent a relevant oceanographic feature in the study region, and indeed many of them were identified during the turtle tracking period. In most 

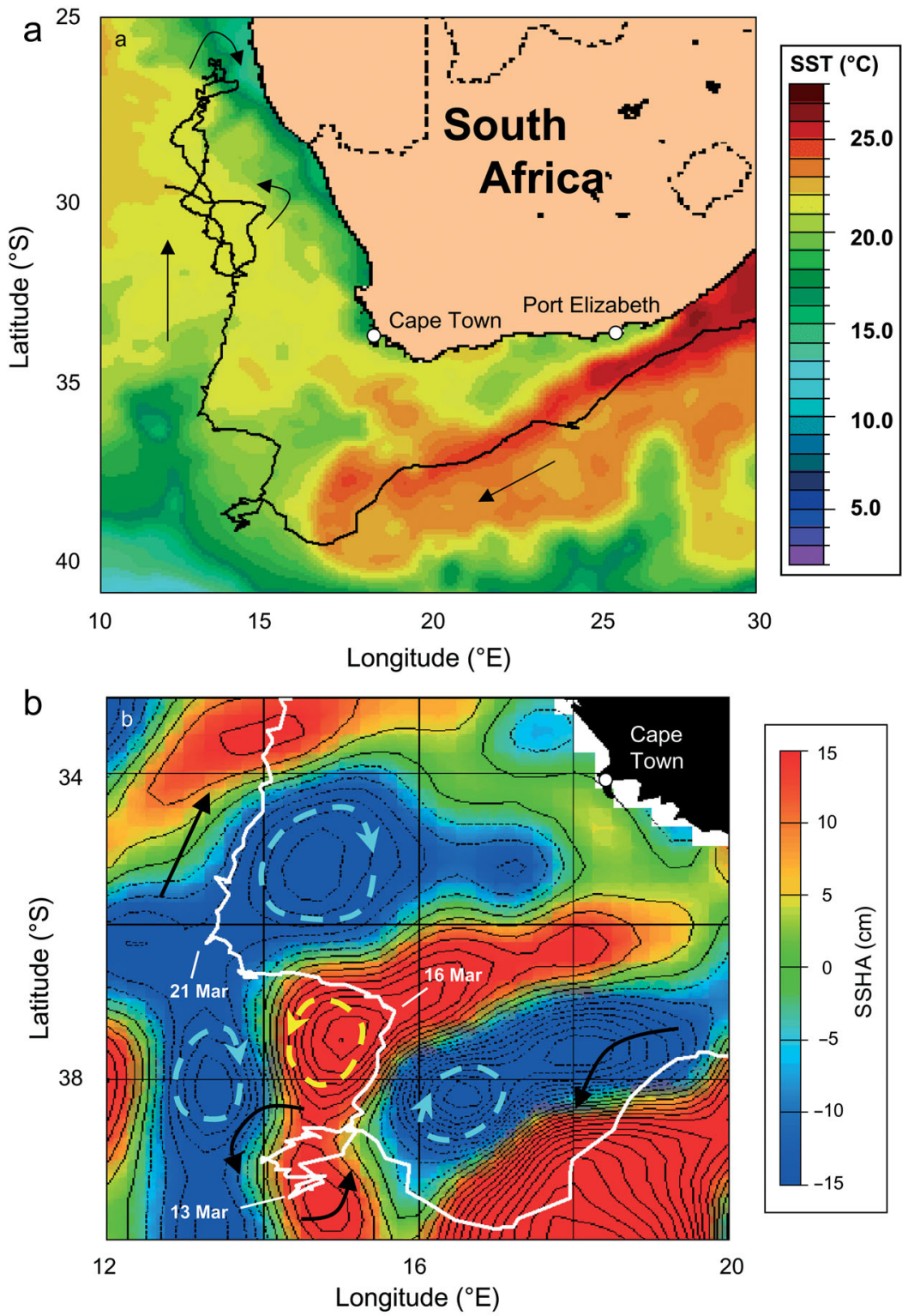

Fig. 5. (a) Route of the turtle 'Sara' as she entered the southern Atlantic Ocean superimposed on a sea surface temperature (SST) image recorded on 15 July 2003. (b) Details of her inter-oceanic shift (dates shown) superimposed on a sea surface height anomaly (SSHA) image recorded on 18 March 2003. Direction of eddy rotation in the area revealed by SSHA indicated by dashed arrows: anticlockwise water movements are associated with anti-cyclonic eddies (positive anomalies; red) and clockwise water movements with cyclonic eddies (negative anomalies; blue). Black arrows indicate the turtle's direction of movement

cases $(61.9 \%)$, the encounter with the rotating water masses within the eddy determined a deflection in the turtles' movement, evident as a curve or a bulge, which was always in accordance with the current sense of rotation. A clear example of this pattern is illustrated by the looping movements of 'Alice' and 'Elena'. 'Alice' moved directly away from the coast (Fig. 6) and continued moving eastward with no evidence whatsoever that she had crossed into or across the Agulhas Current. The positive SSHA present at the coast (red in Fig. 6a), may well support such an inference by indicating the temporary absence of the Agulhas Current itself. Indeed, analysis of the appropriate SSHA images showed that no such anomalies were present offshore when the turtles that moved SW left inshore waters. 'Alice' then found a number of positive and negative SSHA, which most probably were in fact cyclonic and anti-cyclonic eddies, as shown by their characteristic motion poleward (Fig. 6) and by independent investigations (Schouten et al. 2003). During the passage of the first anti-cyclone (red in Fig. 6a,b) the turtle carried out a half orbit around this eddy (21 to 28 February). With the advent of a persisting cyclonic anomaly (Fig. 6b,c), 'Alice' moved in a clockwise manner, encircling this eddy once (1 March to 14 April), despite the fact that the transmitter discontinuous duty cycle prevented a detailed route reconstruction. The turtle then made another shorter loop that led her to encounter a strong anticyclonic eddy (Fig. 6d). Her successive movements were also completely in accordance with the anti-clockwise water motion associated with this large feature.

Although tracked in a different year, 'Resi' (Fig. 7) behaved consistently with 'Alice'. 'Resi' also left the coast at a right angle, but her movement was then diverted anti-clockwise by a passing anti-cyclone (red in Fig. 7a; here

cases, the identified eddies were not ephemeral and were moving either poleward (in the Indian Ocean), or equatorward (in the Atlantic). The 8 turtles tracked in oceanic waters encountered 42 eddies, for a total of

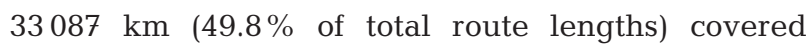
within, or in close association with, eddies.

The turtle routes were usually influenced to some extent by the currents associated with the eddies. In 26 too, location data were received every $6 \mathrm{~d}$ ). Her successive northward path derived from her encounter with poleward-moving eddies, as best illustrated by her loop around (and in accordance with) a strong anomaly farther north (Fig. 7b). 'Resi' finally returned offshore of the nesting beach, at a time when no significant anomaly was present, and then started to move SW (Fig. 2) - a clear indication that 

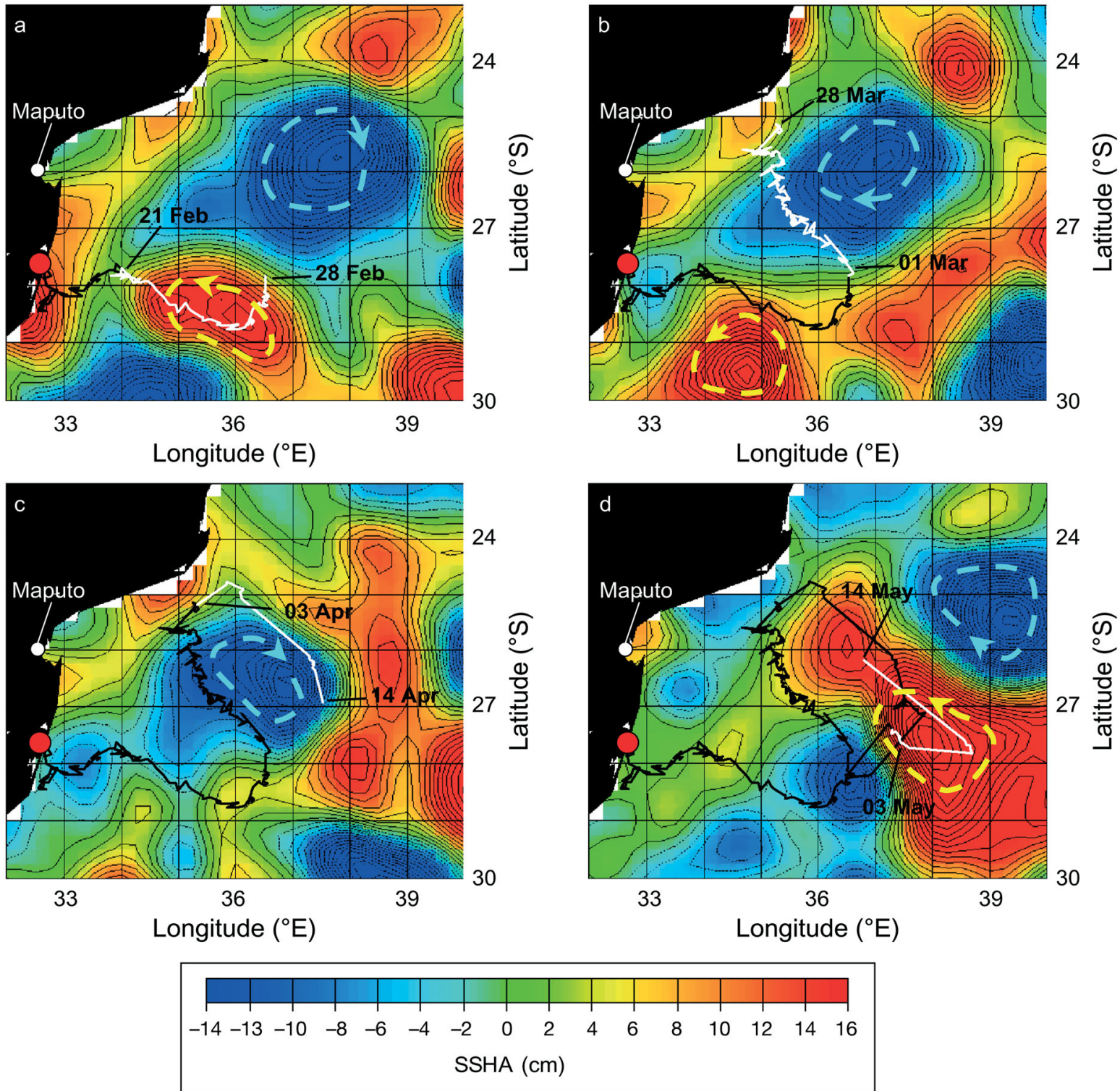

Fig. 6. Initial movements of the turtle 'Alice' upon leaving her nesting beach in 2001 (dates shown), superimposed on sea surface height anomaly (SSHA) maps averaged for 4 successive periods, ending on (a) 28 February, (b) 25 March, (c) 14 April and (d) 10 May 2003. The white parts of the tracks correspond to the $10 \mathrm{~d}$ periods to which the SSHA images refer. The red dot indicates the location of the nesting beach. Other explanations as in Fig. 5

she had been captured by the Agulhas Current mainstream.

In other cases, the turtles remained for a long time within the same eddy, with their routes correspondingly showing 1 or more revolutions. This was observed in 12 instances $(28.6 \%)$, and the track sense of rotation was always in accordance with that of the eddy-associated currents. A good example is provided by the prolonged circuitous movements of 'Nemi' and 'Sandra' discussed by Luschi et al. (2003b).

Finally, in 4 cases $(9.5 \%)$ the turtles passed through eddies with no discernible influence on their routes.
This happened especially with less intense anomalies associated with weaker currents (but see Fig. 1b in Luschi et al. 2003b for a crossing of an intense eddy). For instance, during the northward movement offshore of Namibia, 'Sara' encountered 2 eddies, but her trajectory was only minimally influenced and she was clearly able to move through them.

We also evaluated how long the turtles remained associated with the eddies they encountered (i.e. independently from the kind of movements displayed during these periods). In some cases, turtles remained within the same persisting eddy for weeks (Luschi et al. 


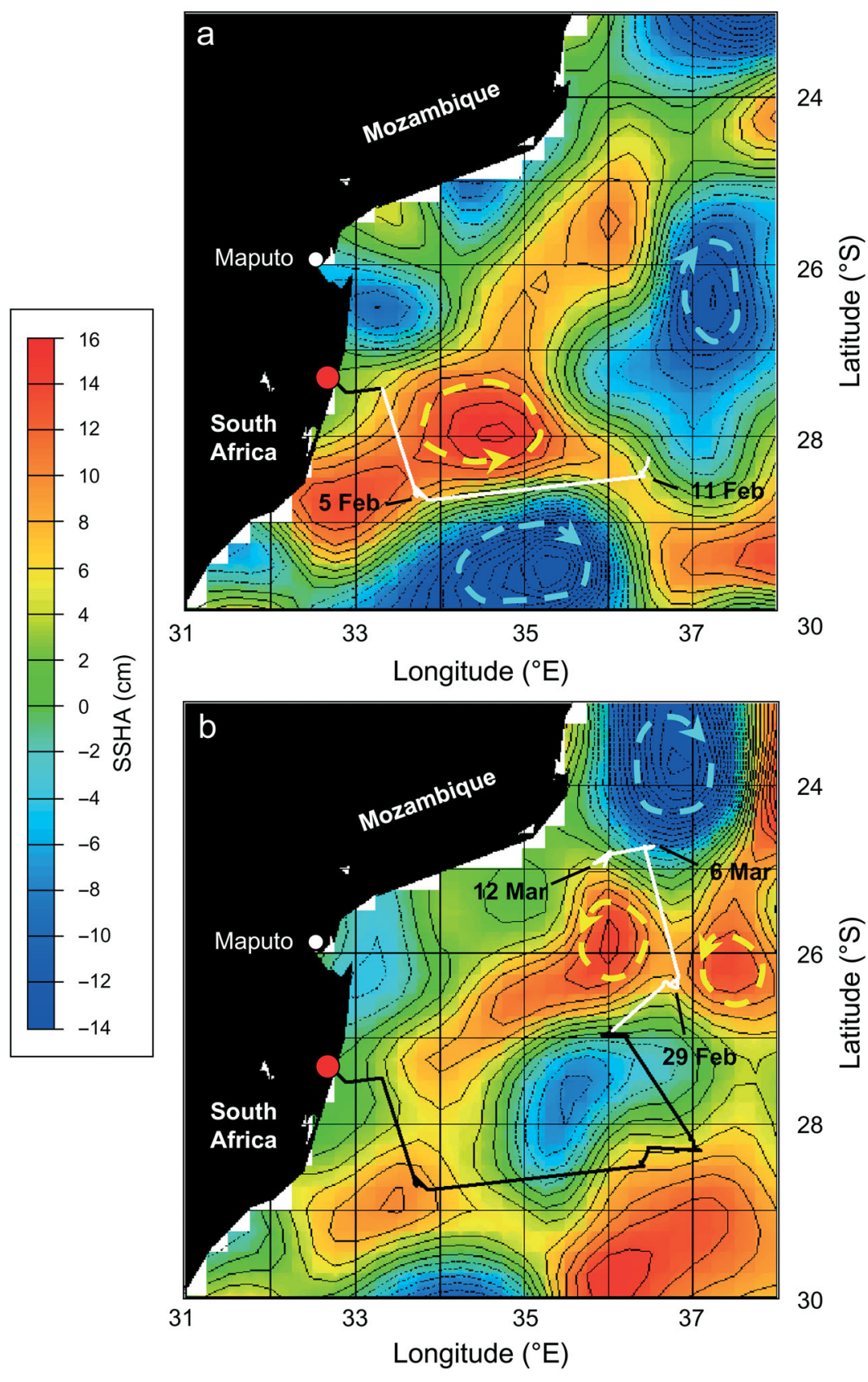

Fig. 7. Initial movements of the turtle 'Resi' in 2000 (dates shown) superimposed on sea suurfface height anomaly (SSHA) maps averaged for 2 successive periods: (a) 1 to 11 February and (b) 2 to 12 March 2003. Other explanations as in Fig. 5

2003b), and sometimes even followed them during their poleward movement (see animation, available as Supplementary Material at www.int-res.com/articles/ suppl/m353p289_app/). A similar behaviour was shown by those turtles that, in the presence of moving eddies, continuously shifted from 1 eddy to another while remaining in the same geographical area, as described above for 'Resi' and 'Alice'.
A prolonged (>1 wk) uninterrupted stay in eddies was observed in 8 instances. In these cases, it is clear that mesoscale features provided profitable foraging opportunities to leatherbacks. Signals of enhanced productivity in the eddies were sometimes detectable in ocean colour images. For instance, the prolonged gyrations of 'Nemi' and 'Sandra' occurred in an area with chl a densities $>0.3 \mathrm{mg} \mathrm{m}^{-3}$, which coincides with a semi-permanent northward bulge in the Subtropical Convergence (Weeks \& Shillington 1996), exhibiting enhanced concentrations of phytoplankton and of higher trophic levels (Lutjeharms et al. 1986, Barange et al. 1998). On the other hand, no enhanced biological activities were observed in the area at about $34^{\circ} \mathrm{S}$, $35^{\circ} \mathrm{E}$ where 'Nemi' circled for 3 mo.

\section{DISCUSSION}

\section{Influence of currents on turtle routes}

By matching satellite tracking data and oceanographic information, we have documented how pelagic-dwelling leatherback turtles are substantially influenced by surface currents and related features during their oceanic movements. This influence takes place at 2 levels. (1) A large percentage of the tracked turtle movements was performed in total accordance with the current flow, either when turtles were moving along the Agulhas Current mainstream or encountered rotating water masses. On average, $73 \%$ of the total tracked routes were determined by currents. For the single turtles (Table 1), this percentage was never less than $65 \%$, the only exception being 'Ronel', for which no clear relationship with currents was established for her long stay in front of the South African coast. (2) Leatherback foraging movements were related to specific oceanographic elements such as mesoscale eddies, convergence or upwelling areas, which concentrate the macroplanktonic resources on which the leatherbacks feed. The planktivorous turtles took advantage of the profitable foraging opportunities offered by these features, often remaining associated with them for prolonged periods. 
The mechanical action of oceanic currents had profound effects on the shape of the turtle routes and produced movement patterns as diverse as straight legs or convoluted looping segments. In the first case, turtles were transported quickly to distant regions, while in the other situation they remained for weeks within the same area. The influences of the currents on the turtle routes often appeared substantial: for 7 turtles, long sections of the routes were virtually indistinguishable from those of inanimate drifters tracked in the same region. This supports previous conclusions (Luschi et al. 2003b) that South African leatherbacks may passively drift with the currents for long periods, although they can also move independently of the currents. Gaspar et al. (2006) quantitatively demonstrated a similar prolonged drift in a leatherback moving in the northern Atlantic Ocean. It is therefore clear that attempting to infer leatherback oceanic behaviour only by considering the reconstructed (ground-related) routes may be misleading.

Under this scenario, extended parts of the leatherback movements derive directly from current advection rather than from a determined effort to swim to specific distant sites, with the turtles possibly concentrating on diving to feed on planktonic prey. The geographical displacements observed would then essentially be a consequence of the fact that the leatherback feeding areas are linked to major current systems, and are spatio-temporally variable either over short periods (i.e. months) or over the long term (i.e. in different years). The turtle association with these movable oceanic features would therefore account for the wide extension of leatherback movements and for their variability, for instance in separate sections of the same route, in routes of turtles tracked in the same period or in subsequent years. Investigation of the influence of sea currents on leatherback movements has been limited to parts covered along oceanic fronts (Ferraroli et al. 2004), and, especially, to a single turtle track in the North Atlantic (Gaspar et al. 2006), where active travelling coexisted with prolonged drifts with the current. Occurrence of legs covered independently or against currents and of segments influenced by oceanographic features has been shown in pelagic-stage loggerhead turtles Caretta caretta (Polovina et al. 2004, 2006).

\section{Leatherback foraging strategies}

We have also shown how leatherbacks nesting in South Africa disperse widely, reaching disparate feeding sites such as the waters north and east of South Africa, the Subtropical Convergence, or the upwelling region off SW Africa. This vast dispersion resembles those known for post-nesting leatherbacks of other populations, which have been recorded on a compara- ble number of individuals ( $\mathrm{n}=8$, Morreale et al. 1996; $\mathrm{n}=7$, Eckert \& Sarti 1997; $\mathrm{n}=12$, Ferraroli et al. 2004; $\mathrm{n}=9$, Hays et al. 2004a,b). In these cases, the presence of segments similar between turtles (especially soon after leaving the nesting areas) coexists with variability in the final destinations and with inter-annual variations in the routes followed. Such a pattern is also evident in leatherbacks tracked during other stages of their life cycle (James et al. 2005).

In our study, most turtles reached foraging areas in the oceanic environment, but in some cases foraging occurred in coastal areas, even close to the nesting beach (e.g. 'Elena'). In particular, the deep-sea eddies off the east coast of Africa represented a most relevant oceanic feature for tracked leatherbacks, which remained associated with the eddies for extended periods or even followed them during their poleward movement. Most likely, eddies form patches of high prey abundance, with turtles tending to remain within them until these resources are totally exploited. Mesoscale oceanographic features support well-structured food chains and are selectively targeted by planktivorous animals like sharks, albatrosses and turtles (Sims \& Quayle 1998, Nel et al. 2001, Ferraroli et al. 2004, Polovina et al. 2006). While the actual profitability of eddies for leatherbacks may not be universal (Hays et al. 2006), in this region such features likely offer valuable feeding opportunities to ocean-moving leatherbacks, therefore constituting a kind of feeding 'hotspot' (Ferraroli et al. 2004, Hays et al. 2006, Polovina et al. 2006), albeit movable, for planktivorous leatherbacks.

One important characteristic of the eddies in this area is their general high mobility, evident both in the Indian and the Atlantic Ocean. As such, the predictability in time and space of these foraging hotspots seems quite limited. This contrasts with other profitable foraging areas of the region such as the Subtropical Convergence and the coastal upwelling region west of the continent. Getting into these areas would even be energetically favourable by riding the Agulhas and Benguela Currents, but this was not the strategy most commonly chosen by the tracked turtles, of which only 3 joined the Convergence or the upwelling zone. It may be somewhat surprising that South African leatherbacks do not aim to reach such predictably profitable areas (at least in the first months after nesting), but rather moved over extensive oceanic areas. Even the rapid SW transfer carried along (and with the help of) the Agulhas Current mainstream does not seem to be due to the need to reach specific foraging sites. One possible reason may be that within the Subtropical Convergence, primary productivity is extremely patchy in time and space (Llido et al. 2005), so resource exploitation may not be particularly 
advantageous, at least no more advantageous than in lower-latitude areas, where food is less concentrated but foraging is possibly equally efficient (e.g. within eddies). No detailed information on the short-scale distribution of the gelatinous zooplankton is available (James et al. 2005), and such subtle information can hardly be derived from remote-sensing data. However, it is worth noting that in some cases this SW leg was postponed ('Resi') or absent for months ('Alice' and 'Ronel'), indicating that leatherbacks do not have an inherent or urgent need to move poleward.

This analysis suggests that South African leatherbacks do not aim to reach specific (e.g. previously visited) destinations during their post-nesting movements, but rather take advantage of whichever suitable oceanographic features they encounter during their largely current-determined movements. Even for those few turtles that have reached predictable features, the arrival into these profitable areas was heavily determined by the current conditions during the journey (e.g. stochastic factors south of the continent), and do not seem to derive from a turtle's deliberate movement toward one site or another. In the North Atlantic, 2 foraging strategies seem to occur in postnesting leatherbacks, with some turtles heading toward predictable feeding hotspots (like high-latitude waters or eddy-rich regions; Ferraroli et al. 2004, James et al. 2005), while others keep moving and continuously forage as they travel over large regions (Hays et al. 2006). South African turtles seem to mainly adopt this latter strategy, having the additional opportunity of encountering movable foraging hotspots such as offshore eddies.

\section{Implications for leatherback biology}

The wide-ranging movements observed and especially the inter-oceanic shifts may play a major role in determining the shallow genetic differences between leatherbacks nesting in the Indian and Western Atlantic Ocean (Dutton et al. 1999). However, since these differences are related to maternal (mtDNA) lineages, other processes such as nest site fidelity and natal beach homing are probably involved in reducing the observed genetic variability. Additionally, the fact that South African leatherbacks do not necessarily engage in long migrations may result in a reduction of their remigration interval between nesting seasons. However, remigration intervals of South African nesting populations (typically 2 to 3 yr; Hughes 1996) are similar to those of Atlantic populations (Boulon et al. 1996, Girondot et al. 2002), although somewhat shorter than in Pacific leatherbacks (Spotila et al. 2000, Reina et al. 2002).
Further, the strong influence of ocean currents on the observed movements raises the issue of the navigational abilities of these turtles. South African leatherbacks return to the same area in successive nesting seasons (Hughes 1996), and such fidelity requires reliance on remarkable navigational abilities if leatherbacks spend the 2 or 3 yr remigration intervals moving over vast areas while being subjected to the current drifting action. In the open sea, such drift cannot be detected, and would take place both when turtles move in accordance with the current flow (i.e. drift) and when they are actively swimming toward specific destinations (Girard et al. 2006). Drift-induced deviations from the intended course are particularly harmful (and navigationally challenging) in the presence of strong and varying currents, as in the present case. A possible help to turtles in relocating the nesting area might come from the existence of large oceanic gyres recirculating most of the water in the South Indian Ocean (Stramma \& Lutjeharms 1997). The same current circulation that leads the turtles away from the nesting area could therefore carry them back to it (or close to it) over some years. Such a system, however, would provide an imprecise way of relocating the nesting beach and is not available to turtles leaving the Indian Ocean gyre, e.g. those entering the Atlantic Ocean. This scenario might explain the irregularity in intervals between nesting seasons exhibited by South African leatherbacks, but could hardly explain their overall nesting beach fidelity and the fact that no leatherback tagged in Tongaland has ever been found nesting anywhere else in the world (Hughes 1996). The best system by which animals subjected to drift can navigate back to a specific site is to possess large-scale position-fixing mechanisms. Reliance on such map-like mechanisms has often been proposed for marine navigators including turtles (Bingman \& Cheng 2005), with experimental evidence having been collected (Lohmann et al. 2004). Such large-scale maps would help turtles subjected to current drift to relocate the nesting beach, if only in estimating how far from their target they have come during their prolonged stay in a movable medium.

Acknowledgements. Funding for satellite tracking experiments was provided by the Italian MiUR, the Italian Space Agency and the UK Natural Environmental Research Council. We are grateful to F. Papi, A. Sale and S. Benvenuti for their help. Three anonymous referees provided useful comments on an earlier version of the manuscript.

\section{LITERATURE CITED}

Alerstam T, Hedenström A, Åkesson S (2003) Long-distance migration: evolution and determinants. Oikos 103:247-260

Barange M, Pakhomov EA, Perissinotto R, Froneman PW, Verheye HM, Taunton-Clark J, Lucas MI (1998) Pelagic community structure of the Subtropical Convergence 
region south of Africa and in the mid-Atlantic Ocean. Deep-Sea Res 45:1663-1687

Beal LM, Bryden HL (1999) The velocity and vorticity structure of the Agulhas Current at $32^{\circ} \mathrm{S}$. J Geophys Res 104: 5151-5176

Bingman VP, Cheng K (2005) Mechanisms of animal global navigation: comparative perspectives and enduring challenges. Ethol Ecol Evol 17:295-318

Boulon RH Jr, Dutton PH, McDonald DL (1996) Leatherback turtles (Dermochelys coriacea) on St. Croix, U.S. Virgin Islands: fifteen years of conservation. Chelonian Conserv Biol 2:141-147

Brierley AS, Axelsen BE, Beucher E, Sparks CAJ, Boyer H, Gibbons MJ (2001) Acoustic observations of jellyfish in the Namibian Benguela. Mar Ecol Prog Ser 210:55-66

de Ruijter WPM, Ridderinkhof H, Lutjeharms JRE, Schouten MW, Veth C (2002) Observations of the flow in the Mozambique Channel. Geophys Res Lett 29:1401-1403

de Ruijter WPM, van Aken HM, Beier EJ, Lutjeharms JRE, Matano RP, Schouten MW (2003) Eddies and dipoles around South Madagascar: formation, pathways and large-scale impact. Deep-Sea Res Part I 51(3):383-400

Dingle H (1996) Migration, the biology of life on the move. Oxford University Press, New York

Duron-Dufrenne M (1987) Premier suivi par satellite en Atlantique d'une tortue Luth Dermochelys coriacea. CR Acad Sci Paris 304:399-402

Dutton PH, Bowen BW, Owens DW, Barragan A, Davis SK (1999) Global phylogeography of the leatherback turtle (Dermochelys coriacea). J Zool (Lond) 248:397-409

Eckert SA (2002) Swim speed and movement patterns of gravid leatherback sea turtles (Dermochelys coriacea) at St Croix, US Virgin Islands. J Exp Biol 205:3689-3697

Eckert SA (2006) High-use oceanic areas for Atlantic leatherback sea turtles (Dermochelys coriacea) as identified using satellite telemetered location and dive information. Mar Biol 149:1257-1267

Eckert SA, Sarti L (1997) Distant fisheries implicated in the loss of the world's largest leatherback nesting population. Mar Turtle Newsl 78:2-7

Ferraroli S, Georges JY, Gaspar P, Le Maho Y (2004) Where leatherback turtles meet fisheries. Nature 429:521-522

Flemming B, Hay R (1988) Sediment distribution and dynamics of the Natal continental shelf. In: Schumann EH (ed) Coastal ocean studies off Natal, South Africa. SpringerVerlag, Berlin, p 47-80

Gaspar P, George JY, Fossette S, Lenoble A, Ferraroli S, Le Maho Y (2006) Marine animal behaviour: neglecting ocean currents can lead us up the wrong track. Proc R Soc Lond B 237:2697-2702

Girard C, Sudre J, Benhamou S, Roos D, Luschi P (2006) Homing in green turtles Chelonia mydas: oceanic currents act as a constraint rather than as an information source. Mar Ecol Prog Ser 322:281-289

Girondot M, Tucker AD, Rivalan P, Godfrey MH, Chevalier J (2002) Density-dependent nest destruction and population fluctuations of Guianan leatherback turtles. Anim Conserv 5:75-84

Gründlingh ML (1983) On the course of the Agulhas Current. S Afr Geogr J 65:49-57

Hays GC, Houghton JDR, Isaacs C, King RS, Lloyd C, Lovell P (2004a) First records of oceanic dive profiles for leatherback turtles (Dermochelys coriacea) indicate behavioural plasticity associated with long distance migration. Anim Behav 67:733-743

Hays GC, Houghton JDR, Myers AE (2004b) Pan-Atlantic leatherback turtle movements. Nature 429:522
Hays GC, Hobson VJ, Metcalfe JD, Righton D, Sims DW (2006) Flexible foraging movements of leatherback turtles across the north Atlantic Ocean. Ecology 87:2647-2656

Hughes GR (1996) Nesting of the leatherback turtle (Dermochelys coriacea) in Tongaland, KwaZulu-Natal, South Africa, 1963-1995. Chelonian Conserv Biol 2:153-158

James MC, Myers RA, Ottensmeyer CA (2005) Behaviour of leatherback sea turtles, Dermochelys coriacea, during the migratory cycle. Proc R Soc Lond B 272:1547-1555

Keinath JA, Musick JA (1993) Movements and diving behavior of a leatherback turtle, Dermochelys coriacea. Copeia 1993:1010-1017

Llido J, Garçon V, Lutjeharms JRE, Sudre J (2005) Event-scale blooms drive enhanced primary productivity at the Subtropical Convergence. Geophys Res Lett 32:L15611

Lohmann KJ, Lohmann CMF, Ehrhart LM, Bagley DA, Swing $\mathrm{T}$ (2004) Geomagnetic map used in sea-turtle navigation. Nature 428:909-910

Luschi P, Hays CG, Papi F (2003a) A review of long-distance movements by marine turtles and the possible role of ocean currents. Oikos 103:293-301

Luschi P, Sale A, Mencacci R, Hughes GR, Lutjeharms JRE, Papi F (2003b) Current transport in leatherback sea turtles (Dermochelys coriacea) in the ocean. Proc R Soc Lond B 270 (Suppl 2):129-132

Lutcavage ME, Rhodin AGJ, Sadove SS, Conroy CR (2002) Direct carapacial attachment of satellite tags using orthopedic bioabsorbable mini-anchor screws on leatherback turtles in Culebra, Puerto Rico. Mar Turtle Newsl 95:9-12

Lutjeharms JRE (2006) The Agulhas Current. Springer-Verlag, Berlin

Lutjeharms JRE, Ansorge I (2001) The Agulhas Return Current. J Mar Syst 30:115-138

Lutjeharms JRE, van Ballegooyen RC (1988) Anomalous upstream retroflection in the Agulhas Current. Science 240(4860):1770-1772

Lutjeharms JRE, Allanson BR, Parker L (1986) Frontal zones, chlorophyll and primary production patterns in the surface waters of the Southern Ocean south of Africa. In: Nihoul JCJ (ed) Marine interfaces ecohydrodynamics. Proc 17th Int Liege Colloquium. Elsevier Oceanography Series, p 105-117

Lutjeharms JRE, Shillington FA, Duncombe Rae CM (1991) Observations of extreme upwelling filaments in the South East Atlantic Ocean. Science 253(5021):774-776

Lutjeharms JRE, Weeks SJ, van Ballegooyen RD, Shillington FA (1992) Shedding of an eddy from the seaward front of the Agulhas Current. S Afr J Sci 88:430-433

Morreale SJ, Standora EA, Spotila JR, Paladino FV (1996) Migration corridor for sea turtles. Nature 384:319-320

Musick JA, Limpus CJ (1997) Habitat utilization and migration in juvenile sea turtles. In: Lutz PL, Musick JA (eds) The biology of sea turtles. CRC Press, Boca Raton, FL, p 137-163

Nel DC, Lutjeharms JRE, Pakhomov EA, Ansorge IJ, Ryan PG, Klages NTW (2001) Exploitation of mesoscale oceanographic features by grey-headed albatross Thalassarche chrysostoma in the southern Indian Ocean. Mar Ecol Prog Ser 217:15-26

Polovina JJ, Balazs GH, Howell EA, Parker DM, Seki MP, Dutton PH (2004) Forage and migration habitat of loggerhead (Caretta caretta) and olive ridley (Lepidochelys olivacea) sea turtles in the central North Pacific Ocean. Fish Oceanogr 13:36-51

Polovina J, Uchida I, Balazs GH, Howell EA, Parker D, Dutton P (2006) The Kuroshio Extension Bifurcation Region: a pelagic hotspot for juvenile loggerhead sea turtles. DeepSea Res Part II 53:326-339 
Reina RD, Mayor PA, Spotila JR, Piedra R, Paladino FV (2002) Nesting ecology of the leatherback turtle, Dermochelys coriacea, at Parque Nacional Marino Las Baulas, Costa Rica: 1988-89 to 1999-2000. Copeia 2002:653-664

Richardson PL, Lutjeharms JRE, Boebel O (2003) Introduction to the 'Inter-ocean exchange around southern Africa'. Deep-Sea Res Part II 50:1-12

Sale A, Luschi P, Mencacci R, Lambardi P, Hughes GR, Hays GC (2006) Long-term monitoring of leatherback turtle diving behaviour during oceanic movements. J Exp Mar Biol Ecol 328:197-201

Schouten MW, de Ruijter WPM, van Leeuwen PJ, Lutjeharms JRE (2000) Translation, decay and splitting of Agulhas rings in the south-eastern Atlantic ocean. J Geophys Res 105:21913-21925

Schouten MW, de Ruijter WPM, van Leeuwen PJ, Ridderinkhof $H$ (2003) Eddies and variability in the Mozambique Channel. Deep-Sea Res Part II 50:1987-2003

Shannon LV, Nelson G (1996) The Benguela: large scale features and processes and system variability. In: Wefer $G$, Berger WH, Siedler G, Webb D (eds) The South Atlantic:

Editorial responsibility: Rory Wilson (Contributing Editor), Swansea, UK present and past circulation. Springer-Verlag, Berlin, p 163-210

Sims DW, Quayle VA (1998) Selective foraging behaviour of basking sharks on zooplankton in a small-scale front. Nature 393:460-464

Spotila JR, Reina RD, Steyermark AC, Plotkin PT, Paladino FV (2000) Pacific leatherback turtles face extinction. Nature 405:529-530

Stewart RH (2003) Introduction to physical oceanography. Available at http://oceanworld.tamu.edu/resources/ocng_ textbook/contents.html

Stramma L, Lutjeharms JRE (1997) The flow field of the subtropical gyre of the South Indian Ocean. J Geophys Res 102:5513-5530

Wedepohl PM, Lutjeharms JRE, Meeuwis JM (2000) The surface drift of the South East Atlantic Ocean. S Afr J Mar Sci 22:71-79

Weeks SJ, Shillington FA (1996) Phytoplankton pigment distribution and frontal structure in the subtropical convergence region south of Africa. Deep-Sea Res 43: $739-768$

Submitted: June 23, 2006; Accepted: June 21, 2007

Proofs received from author(s): December 7, 2007 